Article

\title{
Insect Fluctuating Asymmetry: An Example in Bolivian Peridomestic Populations of Triatoma infestans (Klug, 1834) (Hemiptera: Reduviidae)
}

\author{
Carolina Vilaseca ${ }^{1}$, Carlos F. Pinto ${ }^{1}$, Rodrigo Órdenes-Claveria ${ }^{2}$, David Laroze ${ }^{2} \mathbb{D}$, Marco A. Méndez $^{3,4,5} \mathbb{D}^{\mathbb{D}}$ \\ and Hugo A. Benítez $6,7, * \mathbb{D}$
}

1 Laboratorio de Ecología Química, Universidad Mayor Real y Pontificia San Francisco Xavier de Chuquisaca, Sucre, Bolivia; vilaseca_c@yahoo.com.ar (C.V.); leqcepi@gmail.com (C.F.P.)

2 Instituto de Alta Investigación, Universidad de Tarapacá, Casilla 7D, Arica 1000000, Chile; rodrigo.ordenescl@gmail.com (R.Ó.-C.); dlarozen@uta.cl (D.L.)

3 Laboratorio de Genética y Evolución, Facultad de Ciencias, Universidad de Chile, Santiago 6640022, Chile; mmendez@uchile.cl

4 Center of Applied Ecology and Sustainability (CAPES), Facultad de Ciencias Biológicas, Pontificia Universidad Católica de Chile, Santiago 3580000, Chile

5 Instituto de Ecología y Biodiversidad (IEB), Santiago 6640022, Chile

6 Laboratorio de Ecología y Morfometría Evolutiva, Centro de Investigación de Estudios Avanzados del Maule, Universidad Católica del Maule, Talca 3466706, Chile

7 Centro de Investigación en Recursos Naturales y Sustentabilidad (CIRENYS), Universidad Bernardo O’Higgins, Avenida Viel 1497, Santiago 8370993, Chile

* Correspondence: hbenitez@ucm.cl

check for

updates

Citation: Vilaseca, C.; Pinto, C.F.; Órdenes-Claveria, R.; Laroze, D.;

Méndez, M.A.; Benítez, H.A. Insect Fluctuating Asymmetry: An Example in Bolivian Peridomestic Populations of Triatoma infestans (Klug, 1834) (Hemiptera: Reduviidae). Symmetry 2022, 14, 526. https://doi.org/ $10.3390 /$ sym 14030526

Academic Editors: Stefan Van

Dongen and Paolo Piras

Received: 20 January 2022

Accepted: 1 March 2022

Published: 4 March 2022

Publisher's Note: MDPI stays neutral with regard to jurisdictional claims in published maps and institutional affiliations.

Copyright: (c) 2022 by the authors. Licensee MDPI, Basel, Switzerland. This article is an open access article distributed under the terms and conditions of the Creative Commons Attribution (CC BY) license (https:// creativecommons.org/licenses/by/ $4.0 /)$.

\begin{abstract}
Fluctuating asymmetry (FA) is a morphometric tool used to measure developmental instability in organisms which have been exposed to stress or other adverse conditions. Phenotypic variability in response to stressors are the result of interactions between genomes and the environment, acting in a noisy developmental system. Most of the organisms have bilateral symmetry with a repetition of structures in different positions or orientations; asymmetrical variation has been a morphological response associated with insecticide application inducing disturbances in endocrinal system product of the chemicals. Triatoma infestans (is the main vector of Chagas disease in South America. The availability of food sources varies for populations of T. infestans living in different habitats; insects that inhabit the intradomicile feed preferentially on human blood, whereas insects that develop in the peridomicile feed on the blood of the other mammals and birds. The following research evaluate the FA to the different ecotopes in two geographical areas of Chuquisaca Bolivia; Yamparáez/Sotomayor of the high inter-Andean valleys and Huacaya/Imbochi of the boreal Chaco and a CIPEIN laboratory strain population. A combination of advanced morphometrics tools and multivariate analysis were used to quantify the levels of asymmetry produced by pyretroid near to the peridomiciles in Bolivia. Populations from Yamparáez/Sotomayor were found to have higher levels of FA which the combination of environmental conditions such as low temperatures avoid greater permanence in the habitat and more exposition to insecticide. A better understanding of the combination of these tools will allow researchers to implement better public policies to regulate insecticide applications and to understand how certain organisms adapt to multiple stressors.
\end{abstract}

Keywords: fluctuating asymmetry; pesticides; geometric morphometrics; vector; developmental instability

\section{Introduction}

Triatoma infestans (Klug, 1834) (Hemiptera: Reduviidae: Triatominae) is one of the main vectors of Chagas disease in South America [1-3]. This hematophagous insect, a synanthropic species, has adapted to the human habitat: domestic and peridomestic areas 
(warehouses and pens for domestic animals) [4-6]. Acoording to the World Health Organization, there are 6 million people infected with the parasite Trypanosoma cruzi (Chagas, 1909) (Kinetoplastida, Trypanosomatidae), the causal agent of Chagas disease, in Latin America and it is estimated that 75 million people are at risk of contracting the disease. Complications of chronic disease can be cardiac abnormalities and dilatation of the esophagus and colon [7].

Considering the high epidemiological importance of reducing the vector of Chagas disease transmission in South America, the attempts to eliminate the vector insect in the intra and peridomicile areas started to include spraying insecticides in 1991 [8,9]. In Chuquisaca, Bolivia, they started to use insecticides in 2000 in the intra and peridomicile areas with the purpose of eliminating $T$. infestans. In this way, the indices of intradomiciliary infestation in 2017 were less than 3\% in the inter-Andean valley area; however, in the Chaco area, they were more than $7 \%[10,11]$. In both geographical areas, the infestation rates in the peridomicile area were higher than $14 \%$ [11].

In South American countries such as Bolivia, Argentina and Paraguay, populations of $T$. infestans resistant to pyrethroid insecticides were reported [5,12-16]. Resistance to pyrethroid insecticides in populations of $T$. infestans has been reported in Bolivia using biological test in eggs and nymphs of the first instar [14,16-19]. In the inter-Andean valleys of Chuquisaca, Bolivia, Lardeux et al. carried out studies of T. infestans detecting resistance to pyrethroid and sensitivity to organophosphate and carbamate insecticides [17].

The peridomestic habitat of T. infestans differ substantially between inter-Andean valleys and Chaco; the building materials, the environmental temperature and the relative humidity have an influence on the microenvironments [20]. The availability of food sources varies for populations of $T$. infestans living in different habitats; insects that inhabit the intradomicile feed preferentially on human blood, whereas insects that develop in the peridomicile feed on the blood of other mammals and birds [10]. In addition, these insects are exposed to different levels of environmental pollution or toxic substances, such as insecticides [21]. Stress in insects sometimes can be associated with insecticide application and their development [22-28]. Fluctuating asymmetry (FA) allows monitoring the stress of organism in the laboratory and natural environments, since genetic and environmental changes can increase FA with changes in developmental homeostasis expressed in adult morphology. These disturbances include extreme temperatures and contact with chemicals, and they tend to increase as habitats become geographically marginal; this includes exposure to chemical toxins [29]. Brouwer et al. [30] highlighted the value of the integration of studies combining biochemical, physiological and ecological approaches in their assessment of developmental instability. Eeva et al. [31] tested the combination of this approaches in two hole-nesting passerines where the foods' exposure to heavy metals has induced high levels of FA, on the other hand, Benítez et al. [26] identify high levels of FA related to the effect of pine resin and the stress of pine plantation into native species of beetles which live in the native understory of the plantation.

FA is a random deviation from bilateral symmetry that is normally distributed around a mean of 0 , and it has been widely used to infer developmental instability [32]. FA is considered an approximate measure of environmental and genetic stress [33]. Directional Asymmetry (DA) measures the tendency of a trait to be consistently developed in a different way on the right and left sides of the body, subtle patterns of DA are a phenomenon widespread in animals [34-37].

The factors that influence the development of FA in insects have been widely studied in relation with food and habitat. For example, Benítez et al. [38] conducted a study in Macaria mirthae Vargas et al., 2005 (Lepidoptera: Geometridae), a native moth from Chile (north populations) feeding preferentially on the Fabacea Acacia macracanta Humb. Et Bonpl. ex Willd. (Leguminosae) species. Due to the loss of its habitat, it moves towards Fabacea Leucaena leucocephala (Lamarck) (Leguminosae), showing FA and DA on the left and right wings of $M$. mirthae species; in the specimens, DA was detected in moths that feed on the native plant and FA in the insects of the exotic plant. Nunes et al. [39] carried out a 
study in Apis mellifera (Linnaeus, 1761) (Hymenoptera: Apidae) from 16 locations in five geographical regions of Brazil, located in areas with low and high impact of environmental disturbance. The authors observed the existence of FA in bees in the shape of wings but not in size, in locations with high levels of environmental pressure.

T. infestans with FA have significant association with the food source, habitat, insecticide spraying cycles and seasons related to the dispersal of adult insects from domestic animal pens to the intradomicile [40]. Triatoma infestans that inhabit the intradomicile had lower FA indices compared with specimens of the peridomicile; according to sex, males presented higher FA indices compared with females, males have a greater tendency to the dispersion from one pen to another or the intradomicile [41-43]. FA rates in T. infestans wings were higher before insecticide spraying in the peridomicile area compared with FA rates after chemical treatment [40]. Therefore, the aim of this research is to combine the use of two morphological tools, geometric morphometrics and fluctuating asymmetry, to evaluate the influence of insecticides on the levels of developmental instability and also their relationship with the environmental quality in peridomestic habitats in Bolivia.

\section{Materials and Methods}

\subsection{Study Area}

The study was conducted in two geographical regions of Chuquisaca, Bolivia: one location in the inter-Andean valley: Yamparáez/Sotomayor (Lat. 19 ${ }^{\circ} 19^{\prime} \mathrm{S}$ Long. $65^{\circ} 60^{\prime} \mathrm{O}$ ), high valley, and the other location is Huacaya/Imbochi (Lat. 1948' S Long. 64 $54^{\prime} \mathrm{O}$ ) located in the dry Chaco (Figure 1). According to Navarro and Maldonado [44], the high inter-Andean valleys are found in the Tucumano-Boliviano region, its geographical and environmental characteristics are: altitude more than $2900 \mathrm{~m}$ above sea level with high plateau zones, temperatures are around $15^{\circ} \mathrm{C}$ and humidity $40 \%$ approximately. The dry Chaco region is located at the east of the Eastern Mountain Range, a region of flat arid lands, with temperatures above $30{ }^{\circ} \mathrm{C}$, and low humidity, around $20 \%$, it is called the Bolivian Boreal Chaco region. Both regions are endemic for Chagas disease. In Yampráez/Sotomayor, adult T. infestans were colleted from 10 peridomestics habitats, and in Huacaya/Imbochi, adult insects were collected from 13 peridomestics habitats. Populations of T. infestans in both regions were handled with pyretroid insecticides since the year 2000, with both $T$. infestans populations developing a resistance to pyretroid insecticides once or twice a year [11].

\subsection{Insect Sampling and Preparation}

In total, 69 adults of T. infestans were collected in peridomestic locations (pens and chicken coops). Overall, 28 females and 41 males were distributed as follows: Yamparáez/Sotomayor 14 and 24, Huacaya/Imbochi 14 and 17, females and males, respectively. Between July and August 2018, the capture was carried out for one hour in each pen or chicken coop, using a clamp each individual was introduced in a glass vial and preserved in alcohol (96\%) for further analyses. In the laboratory, wings were mounted on slides with Euparal ${ }^{\circledR}$ for further morphometric analyses, and they were photographed with a Celestron Handheld Digital Microscope pro $5 \mathrm{MP}$.

To compare FA levels of $T$. infestans from two peridomestic environmental (Yamparáez/Sotomayor and Huacaya/Imbochi) we used a control population, reared in our laboratory, standard strain CIPEIN of adult T. infestans, donated by Entomology Laboratory of Programa Chagas from Chuquisaca, Bolivia, first generation in our laboratory: 14 females and 14 males. This strain was developed under controlled conditions of temperature $23{ }^{\circ} \mathrm{C}$ $+/-2$, humidity $50 \%+/-2$ and $12 \mathrm{~h}$ night; $12 \mathrm{~h}$ day. 


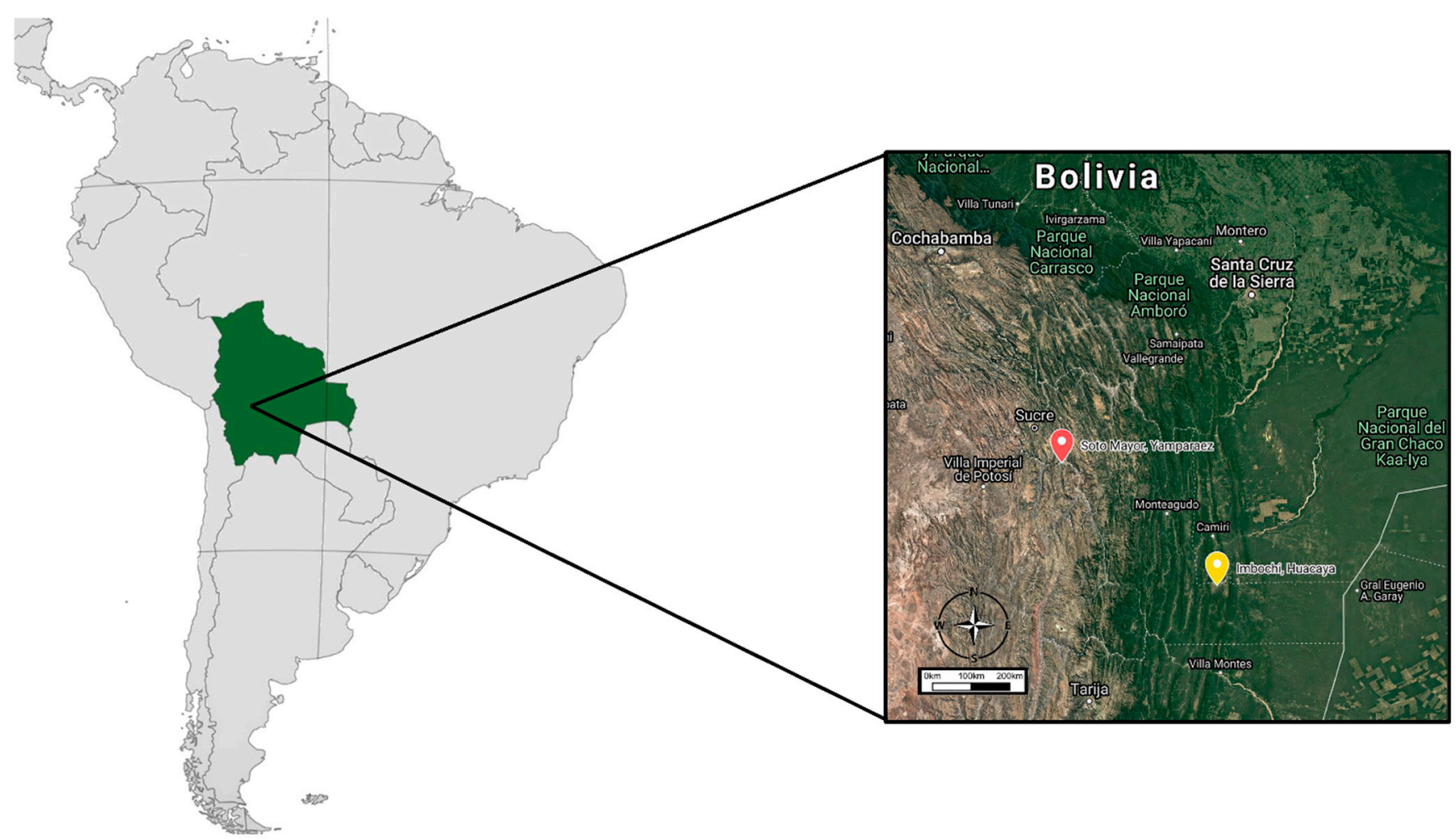

Figure 1. Coordinate information from the Military Institute of Geography for the two locations where Triatoma infestans populations were sampled in Chuquisaca: Sotomayor/Yamparáez (red), Huacaya/Imbochi (yellow).

\subsection{Shape Analyses}

Nine landmarks were digitized, using the software TpsDig 2 V.231 [45], for both right and left wings, according to their external anatomy (Figure 2). The landmarks were aligned applying a Procrustes superimposition method [46]. This procedure removes size, position and orientation information to standardize each specimen based on centroid size. The digitized wings exhibit matching symmetry, which means that the shape analysis included the reflection of all configurations from one body side to its mirror image [36,47]. To calculate the measurement error (ME), the right and left wings were digitized twice [48].

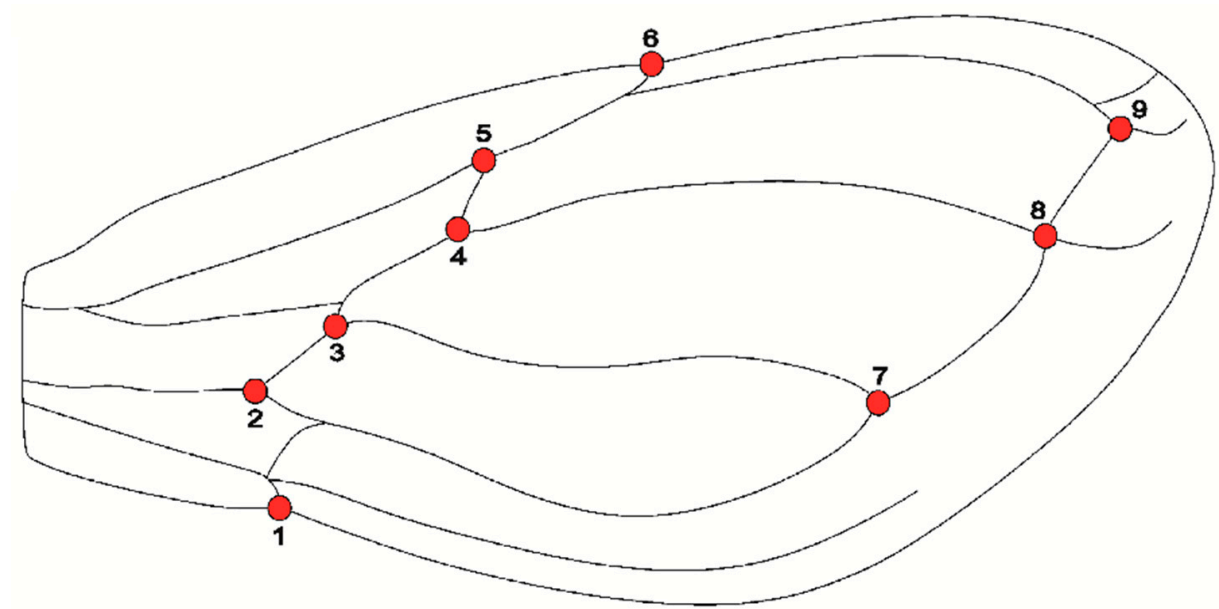

Figure 2. Graphical representation of the wing of $T$. infestans with nine landmarks at the vein intersections. 
Procustes ANOVA is a tool commonly used to analyse asymmetry patterns in morphometric data. The elements of an ANOVA, such as the mean of the squares (MS) and the sum of the squares (SS), which are dimensionless, are essential to evaluate the intensity of the observed asymmetry [36,48]. FA is defined as those random deviation occuring between the left and right sides in a bilateral organism. It is the variation of the individual asymmetry vectors around the means of all the configurations from each side [49].

Following the Protocol of Benítez et al. [27] a comparison between FA intensities was performed by the MS values of shape from a Procrustes ANOVA and a multivariate regression of shape vs. Procrustes FA Scores, using the Procrustes distances of the asymmetry component of the data. Finally, in order to see morphometric differentiation between populations, a Principal component analysis (PCA) was performed with the covariance matrix of wing shape using the software MorphoJ $1.06 \mathrm{~d}$ [50].

\section{Results}

The measurement error was assessed in all the populations studied, in order to avoid any type of error associated with the data. The results of a Procrustes ANOVA indicated that MS values of FA (Ind*side) exceeded the MS values of error, implying that there is no ME in the data (Tables 1-3).

Table 1. Procrustes ANOVA for both centroid size and shape from CIPEIN Popualtion Triatoma infestans, (dimensionless) characterized by matching symmetry. Sums of squares (SS) and mean squares (MS) are in units of Procrustes distances.

\begin{tabular}{|c|c|c|c|c|c|c|c|}
\hline $\begin{array}{l}\text { Centroid } \\
\text { Size/Effect }\end{array}$ & SS & MS & df & $\mathbf{F}$ & $p$ & Pillai tr. & $p$ (Param) \\
\hline Individual & $1,267,588$ & 0.469477 & 27 & 12.13 & $<0.0001$ & & \\
\hline Side & $1,312,120$ & 131.212 & 1 & 33.90 & $<0.0001$ & & \\
\hline Ind*Side & $1,044,953$ & 0.038702 & 27 & 1.85 & 0.026 & & \\
\hline Error 1 & 116,915 & 0.020888 & 56 & & & & \\
\hline \multicolumn{8}{|c|}{ Shape/Effect } \\
\hline Individual & 0.06646813 & 0.000175842 & 378 & 2.52 & $<0.0001$ & 9.38 & $<0.0001$ \\
\hline Side & 0.00176474 & 0.000126003 & 14 & 1.81 & 0.0358 & 0.76 & 0.0203 \\
\hline Ind*Side & 0.0263932 & 0.000697337 & 378 & 3.08 & $<0.0001$ & 7.57 & $<0.0001$ \\
\hline Error & 0.0177762 & 0.0000226737 & 784 & & & & \\
\hline
\end{tabular}

Table 2. Procrustes ANOVA for both centroid size and shape from Yamparáez/Sotomayor Population T. infestans, (dimensionless) characterized by matching symmetry. Sums of squares (SS) and mean squares (MS) are in units of Procrustes distances.

\begin{tabular}{|c|c|c|c|c|c|c|c|}
\hline $\begin{array}{l}\text { Centroid } \\
\text { Size/Effect }\end{array}$ & SS & MS & df & $\mathbf{F}$ & $p$ & Pillai tr. & $p$ (Param) \\
\hline Individual & $46,357,914$ & $1,252,917$ & 37 & 4.99 & $<0.0001$ & & \\
\hline Side & $1,439,198$ & $1,439,198$ & 1 & 5.73 & 0.0218 & & \\
\hline Ind ${ }^{*}$ Side & $9,286,172$ & 0.250978 & 37 & 20.33 & $<0.0001$ & & \\
\hline Error 1 & 0.938393 & 0.012347 & 76 & & & & \\
\hline \multicolumn{8}{|c|}{ Shape/Effect } \\
\hline Individual & 0.20439244 & 0.0003945800 & 518 & 2.01 & $<0.0001$ & 8.81 & $<0.0001$ \\
\hline Side & 0.00641765 & 0.0004584037 & 14 & 2.34 & 0.0039 & 0.64 & 0.008 \\
\hline Ind ${ }^{*}$ Side & 0.10166526 & 0.0001962650 & 518 & 2.61 & $<0.0001$ & 9.17 & $<0.0001$ \\
\hline Error & 0.08004337 & 0.000075287 & 1064 & & & & \\
\hline
\end{tabular}


Table 3. Procrustes ANOVA for both centroid size and shape of Huacaya/Imbochi Population T. infestans, (dimensionless) characterized by matching symmetry. Sums of squares (SS) and mean squares (MS) are in units of Procrustes distances.

\begin{tabular}{|c|c|c|c|c|c|c|c|}
\hline $\begin{array}{l}\text { Centroid } \\
\text { Size/Effect }\end{array}$ & SS & MS & df & $\mathbf{F}$ & $p$ & Pillai tr. & $p$ (Param) \\
\hline Individual & $661,088,646,217$ & $2,203,628,821$ & 30 & 1.00 & 0.4993 & & \\
\hline Side & $220,987,792$ & $220,987,792$ & 1 & 1.00 & 0.3245 & & \\
\hline Ind*side & $6,606,556,014$ & $2,202,185,338$ & 30 & 1.00 & 0.4835 & & \\
\hline Error 1 & $1,363,261,983$ & $219,880,965$ & 62 & & & & \\
\hline \multicolumn{8}{|c|}{ Shape/Effect } \\
\hline Individual & 0.10800141 & 0.000257146 & 420 & 4.09 & $<0.0001$ & 10.75 & $<0.0001$ \\
\hline Side & 0.00132375 & 0.0000945536 & 14 & 1.5 & 0.1065 & 0.89 & $<0.0001$ \\
\hline Ind*Side & 0.02643423 & 0.0000629386 & 420 & 5.28 & $<0.0001$ & 7.48 & $<0.0001$ \\
\hline Error & 0.08004337 & 0.000075287 & 1064 & & & & \\
\hline
\end{tabular}

A significant level of FA (Ind*side: $p<0.0001$ ) was found in CIPEIN individuals (Table 1), with a regular FA intensity in comparison with the other two populations, suggesting that part of the asymmetry in the F1 (first generation) of the control population (Table 4) is due to genetic influence.

After analyzing the peridomestic populations, FA was found in specimens from Huacaya/Imbochi and Yamparáez/Sotomayor (Ind*side: $p<0.0001$ ) (Tables 1 and 2). Nevertheless, after a multivariate regression of Shape vs. Procrustes FA Scores intensity was found to be higher in T. infestans from Yamparáez/Sotomayor than specimens from Huacaya/Imbochi (Table 4 and Figure 3).

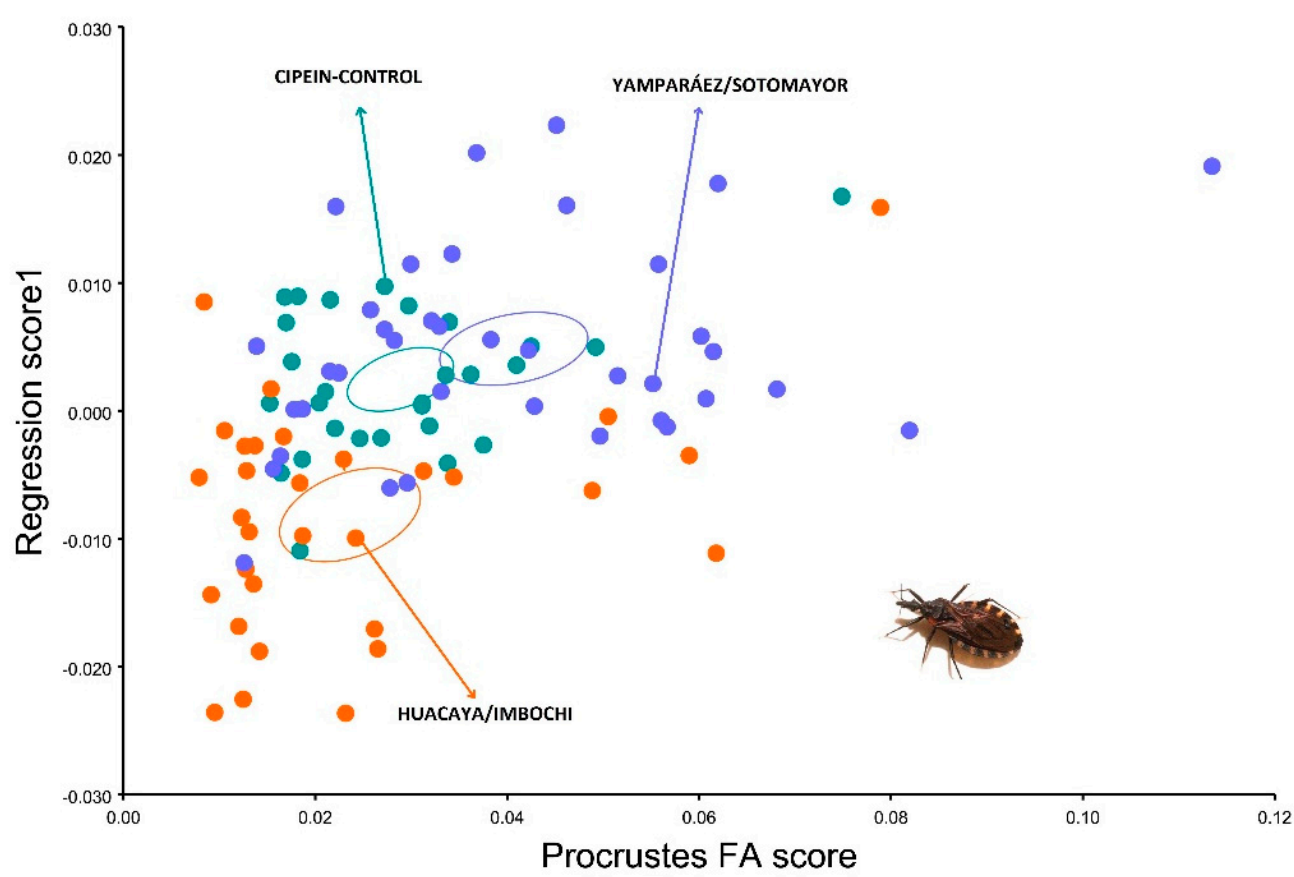

Figure 3. Multivariate regression of Shape as a dependent variable vs. Procrustes FA Scores as an independent variable, showing the intensity of FA between groups. Colors: Green: Cipein-Control, Orange: Huacaya/Imbochi, Blue: Yamparáez/Sotomayor. 
Table 4. Intensity of Fluctuating Asymmetry between populations and sex in T. infestans Mean Squares (MS) AND Pillai tree data of Procrustes ANOVA of shape.

\begin{tabular}{lllll}
\hline Population & Sex & $\mathbf{N}^{\circ}$ of Insects & MS (Ind*Side) & Pillai tr. \\
\hline \multirow{2}{*}{ Yamparáez/Sotomayor } & Female & 14 & 0.0001970676 & 7.98 \\
& Male & 24 & 0.0001892431 & 8.43 \\
\hline \multirow{2}{*}{ Huacaya/Imbochi } & Female & 14 & 0.0000751902 & 7.05 \\
& Male & 17 & 0.0000546154 & 6.22 \\
\hline \multirow{2}{*}{ CIPEIN } & Female & 14 & 0.0000692699 & 7.18 \\
& Male & 14 & 0.0000724677 & 7.04 \\
\hline
\end{tabular}

In order to assess the FA influence by sexes, a Procrustes ANOVA was performed in every population by sex, displaying that females in T. infestans from both peridomestic populations showed higher levels of FA compared with male populations (Table 4).

A principal component analysis showed a morphospace where the first three PC's accumulate $56.4 \%$ of the shape variation (PC1: $27.8 \%$, PC2: $15.2 \%$ PC3: $13.4 \%$ ), displaying a well-defined shape differentiation between populations Although Yamparáez/Sotomayor showed more disparity wing shapes in comparison with the other two population, wing shape vary principally by the movement of the wing veins, displaying wider wings in the populations of Yamparáez/Sotomayor and, on the contrary, more elongated wings with less intraspecific variation in populations of Huacaya/Imbochi were noticeable ovalated and had wider wings than the control population of CIPEIN (Figure 4).

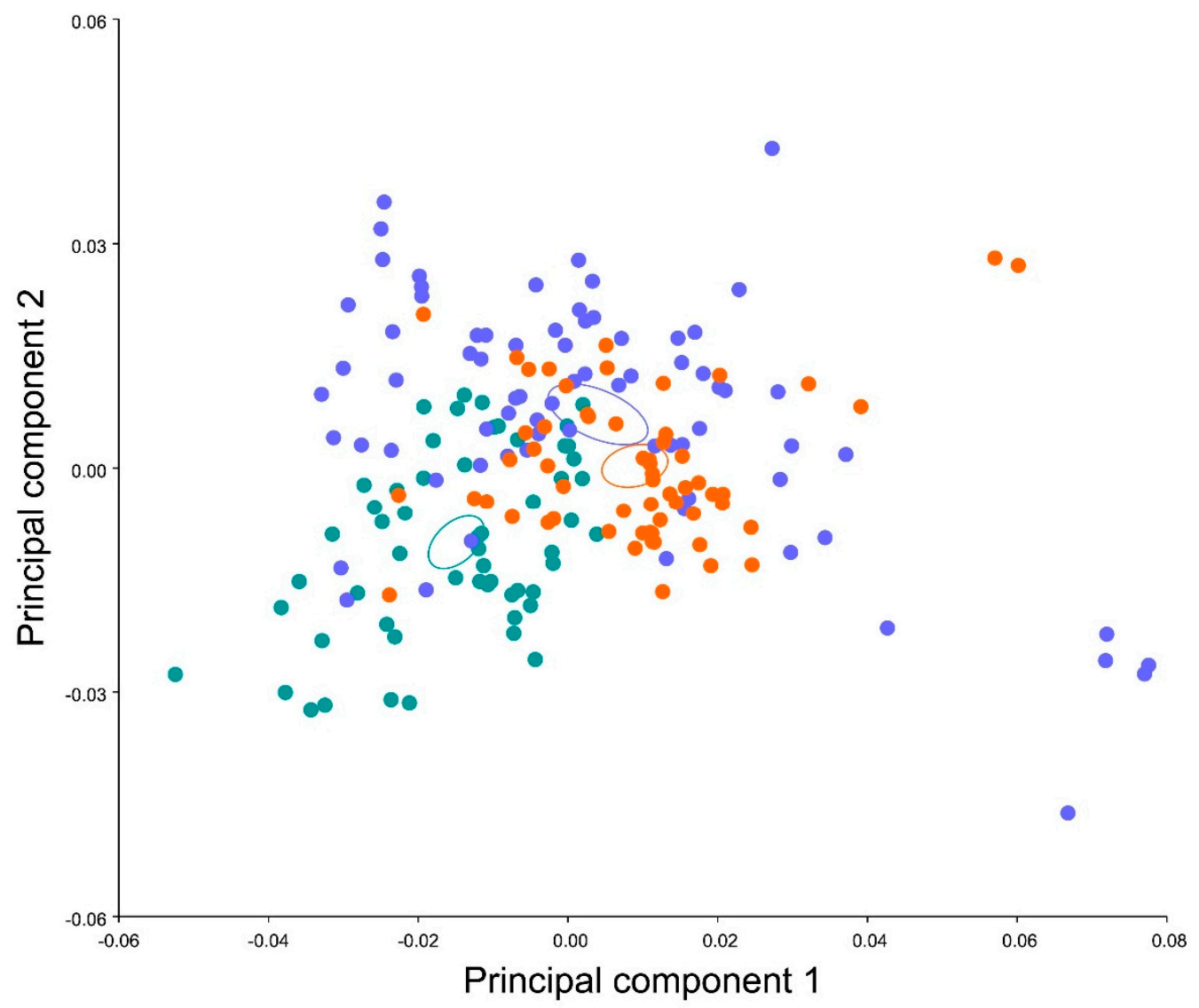

Figure 4. Principal component analysis of the wing shape between three populations in T. infestans. Colors: Green: CIPEIN-Control, Orange: Huacaya/Imbochi, Blue: Yamparáez/Sotomayor. 


\section{Discussion}

It is well known that FA is a measure of developmental instability (DI) [27,51-54]. According to Palmer and Strobeck [29], the visible and measurable asymmetry of right and left sides of the wings of $T$. infestans could be the expression of random disturbances accumulated during development [29]. Populations more exposed to environmental stress show high levels of DI, unlike a "control" population or populations with little exposure [55]. Several stress factors can be present, such as extreme temperatures, food source quality from hosts, stress from environmental pollution and chemical products such as insecticides [21,26,28,33,56-59].

According to Nattero et al. [41], T. infestans from open peridomestic habitats are more likely to exhibit FA in the shape compared with domiciliary insects; in addition, FA in insects that inhabit the peridomicile is related to the quality of food sources of hosts, ecotopes and sex. In our study, control population (CIPEIN) were reared under stable laboratory conditions (temperature and humidity) and fed blood from chickens, principally due to the fact that they were not exposed to any insecticide application. This population showed lower values of FA compared with the peridomestic populations from Yamparáez/Sotomayor and Huacaya/Imbochi. Female T. infestans from Huacaya/Imbochi have significant differences in FA in wing shape compared with males. According to the characteristics of the goat pens and chicken coops built with sticks and palm trees, and open ecotopes, males have the advantage of flying from the peridomicile to human dwelling buildings because they have predisposition to feed on human blood; however, females are less demanding and limit themselves to staying in pens an chicken coops. On the other hand, the environmental temperature is between 25 to $30^{\circ} \mathrm{C}$ in winter, allowing the flight of male triatomines mainly at night $[4,6,60]$.

Similar data were obtainned by Nattero et al. (2015) in the location of Figueroa, in the northwest of Argentina. The wing asymmetry patterns of females living in goat pens were significantly different to that of males, because females have less mobility between habitats. A different condition occurs with the T. infestans population from Yamparáez/Sotomayor, which presented slightly increased levels of FA in shape and size, compared with the population from Huacaya/Imbochi and the CIPEIN "control" strain. In Yamparáz/Sotomayor the environmental temperature is lower than $15^{\circ} \mathrm{C}$ in winter and the humidity is more than $40 \%$, besides the pens and chicken coops are built with blocks of soil, leading to an unfavorable environment for the development of T. infestans. These characteristics avoid flying and infesting other peridomestic and domiciliary environments, low temperatures do not allow flight for T. infestans [61-63]. Males remain in their habitat, feeding on their hosts like females; this population of female insects showed an increase of FA compared with males. Nattero et al. [42] followed up peridomestic sities in the northwest of Argentina, and showed that FA patterns were not stable in T. infestans and depend on the characteristics of habitat and season of the year. Moreover, it seems to be modified by the history of insecticide spraying, either through direct effects on the development of insects or through indirect effects related with flight and invasion of human dwelling habitats.

In our study, the collection of insects was carried out in the peridomicile in winter, six months after insecticide were sprayed in Yamparáez/Sotomayor, and two years after chemical treatment in Huacaya/Imbochi. T. infestans from Yamparáez/Sotomayor received chemical treatment with pyretroid insecticides, (deltamethrin and alpha-cipermethrin) for 17 years (two applications a year) [11], developing resistance according to a research conducted by Lardeux et al. [17] It is possible that regular contacts with insecticides are related with the presence of FA in this population [29]. The FA present in populations collected in natural environments (peridomiciliary) could be related to exposure to the toxic action of insecticides [22,40]. The populations of T. infestans from Huacaya/Imbochi were also treated with pyretroid (deltamethrin) and organophosphates (bendiocarb), but the treatment cycles were less frequent for 17 years (one cycle or less a year) and this insects also developing resistance to pyretroid insecticides [17]. In Huacaya/Imbochi, chemical control in peridomestic environments has been historically difficult because of cultural 
practices and the low availability of chemicals [11]. Furthermore, the construction of pens and chicken coops is precarious and the insecticide is easily eliminated by environmental factors, such as rain and solar rays, which contribute to the degradation of insecticides [64]. Moreover, in phenological stages such as eggs, the insecticide is not efective, and the insects survive and reinfest [65]. However, insecticides have a repellent effect and T. infestans inhabit other peridomiciliary environments [60]. A study conducted by Nattero et al. [40] indicates that before fumigations, FA levels in wings of T. infestans were higher than after chemical treatment, mentioning that this pattern may be related to a selective survival adaptation to insecticides, that may or may not be mediated by resistance to pyrethoids and may be associated with feeding success. Genetic disturbances include intense directional selection and certain specific genes [66]. Both populations have been in constant contact with insecticides, developing a resistance to pyrethroids. Lardeux et al. [17] carried out a biological test to detect the sensitivity to deltamethrin of the populations of $T$. infestans from Yamparáez/Sotomayor and Huacaya, reporting $58 \%$ and $67 \%$, respectively.

\section{Conclusions}

The following research confirms the presence of developmental instability in T. infestans by the quantification of FA. T. infestans was found to be sensible for the environmental conditions from the different peridomiciliary population studied, and was also found to be sensible for insecticide application. The results were found to relate the levels of FA to places more exposed to insecticides during a sustained period of time. There are still no reports of the identification of genes for resistance to insecticides in both populations. Although FA was detected in both populations studied, the population of T. infestans from Yamparáez/Sotomayor presented higher levels of FA that could be associated with higher levels of stress related to environmental characteristic, microhabitat and greater exposure to insecticides. Therefore, the combination of environmental characteristics such as temperature, relative humidity of the environment, preference in feeding according to the source, characteristics of peridomestic habitats, and resistance to insecticides, are one of the main factors that influence the development of FA in wings in populations of T. infestans from Yamparáez/Sotomayor and Huacaya/Imbochi, regions in Chuquisaca Bolivia. More multifactorial studies are needed with the combination of genomic and transcriptomic analyses which can relate the particular substance of the insecticide to the levels of FA in the different populations, which are the next steps for this research.

Author Contributions: Conceptualization, C.V., C.F.P. and H.A.B.; methodology, C.V. and H.A.B.; software, C.V., R.Ó.-C., D.L. and H.A.B.; validation, H.A.B. and C.F.P. and M.A.M.; formal analysis, C.V. and H.A.B.; investigation, C.V., C.F.P., M.A.M., D.L., R.Ó.-C. and H.A.B.; resources, C.V., M.A.M. and H.A.B.; data curation, C.V. and C.F.P.; writing-original draft preparation, C.V. and H.A.B.; writing-review and editing, C.V., C.F.P., M.A.M., D.L., R.Ó.-C. and H.A.B.; supervision, H.A.B.; project administration, H.A.B., M.A.M. and D.L.; funding acquisition, C.V., H.A.B., M.A.M. and D.L. All authors have read and agreed to the published version of the manuscript.

Funding: This research received support from the BOL-01 grant from the International Science Program at Uppsala University and ANID-FONDECYT 12000419 of Chilean government.

Institutional Review Board Statement: Not applicable.

Informed Consent Statement: Not applicable.

Data Availability Statement: Not applicable.

Acknowledgments: The authors thank Edgar Gumiel, Alberto Llanos, Carlos Plaza and all technicians at Program Chagas of SEDES-Chuquisaca for their collaboration in specimen capture, M.A.M. thanks to ANID-FONDECYT 12000419 of Chilean government for partially finance this project and Maria Raquel Lazo de la Vega for provide the proofreading of the manuscript.

Conflicts of Interest: The authors declare no conflict of interest. 


\section{References}

1. Noireau, F.; Carbajal-de-La-Fuente, A.L.; Lopes, C.M.; Diotaiuti, L. Some considerations about the ecology of Triatominae. An. Acad. Bras. Ciências 2005, 77, 431-436. [CrossRef] [PubMed]

2. Noireau, F.; Cortez, M.G.R.; Monteiro, F.A.; Jansen, A.M.; Torrico, F. Can wild Triatoma infestans foci in Bolivia jeopardize Chagas disease control efforts? Trends Parasitol. 2005, 21, 7-10. [CrossRef] [PubMed]

3. Richer, W.; Kengne, P.; Cortez, M.R.; Perrineau, M.M.; Cohuet, A.; Fontenille, D.; Noireau, F. Active dispersal by wild Triatoma infestans in the Bolivian Andes. Trop. Med. Int. Health 2007, 12, 759-764. [CrossRef] [PubMed]

4. Ceballos, L.; Vazquez-Prokopec, G.; Cecere, M.; Marcet, P.; Gürtler, R. Feeding rates, nutritional status and flight dispersal potential of peridomestic populations of Triatomainfestans in rural northwestern Argentina. Acta Trop. 2005, 95, 149-159. [CrossRef] [PubMed]

5. $\quad$ Cecere, M.C.; Vazquez-Prokopec, G.M.; Gürtler, R.E.; Kitron, U. Spatio-temporal analysis of reinfestation by Triatoma infestans (Hemiptera: Reduviidae) following insecticide spraying in a rural community in northwestern Argentina. Am. J. Trop. Med. Hyg. 2004, 71, 803. [CrossRef]

6. Gürtler, R.E.; Cecere, M.C.; Vázquez-Prokopec, G.M.; Ceballos, L.A.; Gurevitz, J.M.; Fernández, M.D.P.; Kitron, U.; Cohen, J.E. Domestic animal hosts strongly influence human-feeding rates of the Chagas disease vector Triatoma infestans in Argentina. PLoS Negl. Trop. Dis. 2014, 8, e2894. [CrossRef]

7. Herrera, L. Trypanosoma cruzi, the causal agent of Chagas disease: Boundaries between wild and domestic cycles in Venezuela. Front. Public Health 2014, 2, 259. [CrossRef]

8. Kirchhoff, L.V. Chagas disease: American trypanosomiasis. Infect. Dis. Clin. N. Am. 1993, 7, 487-502. [CrossRef]

9. World Health Organization. Chagas disease (American trypanosomiasis)—Factsheet (revised in August 2012). Wkly. Epidemiol. Rec. Relev. Épidémiologique Hebd. 2012, 87, 519-522.

10. Vilaseca, C.; Méndez, M.A.; Pinto, C.F.; Lemic, D.; Benítez, H.A. Unraveling the Morphological Variation of Triatoma infestans in the Peridomestic Habitats of Chuquisaca Bolivia: A Geometric Morphometric Approach. Insects 2021, 12, 185. [CrossRef]

11. Chuquisaca, P.C. Informe Anual de Índices de Infestaciónpor Triatoma infestans en el Intra y peri Domicilio en Chuquisaca; Ministerio de Salud y Deportes de Bolivia: Sucre, Bolivia, 2017.

12. Gonzalez-Valdivieso, F.E.; Sanchez Diaz, B.; Nocerino, F. Susceptibility of R. prolixux to Chlorinated Hydrocarbon Insecticides in Venezuela; World Health Organization: Geneva, Switzerland, 1971.

13. Picollo, M.I.; Vassena, C.; Orihuela, P.S.; Barrios, S.; Zaidemberg, M.; Zerba, E. High resistance to pyrethroid insecticides associated with ineffective field treatments in Triatoma infestans (Hemiptera: Reduviidae) from Northern Argentina. J. Med. Entomol. 2005, 42, 637-642. [CrossRef]

14. Acevedo, G.R.; Cueto, G.M.; Germano, M.; Orihuela, P.S.; Cortez, M.R.; Noireau, F.; Picollo, M.I.; Vassena, C. Susceptibility of sylvatic Triatoma infestans from Andeans valleys of Bolivia to deltamethrin and fipronil. J. Med. Entomol. 2011, 48, 828-835. [CrossRef]

15. Santo-Orihuela, P.L.; Carvajal, G.; Picollo, M.I.; Vassena, C.V. Toxicological and biochemical analysis of the susceptibility of sylvatic Triatoma infestans from the Andean Valley of Bolivia to organophosphate insecticide. Memórias Inst. Oswaldo Cruz 2013, 108, 790-795. [CrossRef]

16. Germano, M.; Santo-Orihuela, P.; Roca-Acevedo, G.; Toloza, A.; Vassena, C.; Picollo, M.; Mougabure-Cueto, G. Scientific evidence of three different insecticide-resistant profiles in Triatoma infestans (Hemiptera: Reduviidae) populations from Argentina and Bolivia. J. Med. Entomol. 2014, 49, 1355-1360. [CrossRef]

17. Lardeux, F.; Depickère, S.; Duchon, S.; Chavez, T. Insecticide resistance of Triatoma infestans (Hemiptera, Reduviidae) vector of Chagas disease in Bolivia. Trop. Med. Int. Health 2010, 15, 1037-1048. [CrossRef]

18. Santo-Orihuela, P.L.; Vassena, C.V.; Carvajal, G.; Clark, E.; Menacho, S.; Bozo, R.; Gilman, R.H.; Bern, C.; Marcet, P.L. Toxicological, enzymatic, and molecular assessment of the insecticide susceptibility profile of Triatoma infestans (Hemiptera: Reduviidae, Triatominae) populations from rural communities of Santa Cruz, Bolivia. J. Med. Entomol. 2017, 54, 187-195. [CrossRef]

19. Depickère, S.; Buitrago, R.; Siñani, E.; Baune, M.; Monje, M.; Lopez, R.; Waleckx, E.; Chavez, T.; Brenière, S.F. Susceptibility and resistance to deltamethrin of wild and domestic populations of Triatoma infestans (Reduviidae: Triatominae) in Bolivia: New discoveries. Memórias Inst. Oswaldo Cruz 2012, 107, 1042-1047. [CrossRef]

20. Vilaseca, C.; Méndez, M.A.; Pinto, C.F.; Benítez, H.A. Assessment of Shape Variation Patterns in Triatoma infestans (Klug 1834) (Hemiptera: Reduviidae: Triatominae): A First Report in Populations from Bolivia. Insects 2020, 11, 274. [CrossRef]

21. Parsons, P. Fluctuating asymmetry: A biological monitor of environmental and genomic stress. Heredity 1992, 68, 361-364. [CrossRef]

22. Abaga, N.O.Z.; Alibert, P.; Dousset, S.; Savadogo, P.W.; Savadogo, M.; Sedogo, M. Insecticide residues in cotton soils of Burkina Faso and effects of insecticides on fluctuating asymmetry in honey bees (Apis mellifera Linnaeus). Chemosphere 2011, 83, 585-592. [CrossRef]

23. Benítez, H.A.; Briones, R.; Jerez, V. Intra and Inter-population morphological variation of shape and size of the Chilean magnificent beetle, Ceroglossus chilensis in the Baker River Basin, Chilean Patagonia. J. Insect Sci. 2011, 11, 1-9. [CrossRef]

24. Chang, X.; Zhai, B.; Wang, M.; Wang, B. Relationship between exposure to an insecticide and fluctuating asymmetry in a damselfly (Odonata, Coenagriidae). Hydrobiologia 2007, 586, 213-220. [CrossRef] 
25. Ribeiro, B.; Guedes, R.; Corrêa, A.; Santos, C. Fluctuating asymmetry in insecticide-resistant and insecticide-susceptible strains of the maize weevil, Sitophilus zeamais (Coleoptera: Curculionidae). Arch. Environ. Contam. Toxicol. 2007, 53, 77-83. [CrossRef]

26. Benítez, H.; Briones, R.; Jerez, V. Fluctuating asymmetry in two populations of Ceroglossus chilensis (Eschscholtz, 1829) (Coleoptera: Carabidae) in agroecosystem of Pinus radiata d. Don, Bio-Bio region, Chile. Gayana 2008, 72, 131-139.

27. Benítez, H.A.; Lemic, D.; Villalobos-Leiva, A.; Bažok, R.; Órdenes-Claveria, R.; Pajač Živković, I.; Mikac, K.M. Breaking Symmetry: Fluctuating Asymmetry and Geometric Morphometrics as Tools for Evaluating Developmental Instability under Diverse Agroecosystems. Symmetry 2020, 12, 1789. [CrossRef]

28. Ivanković Tatalović, L.; Anđelić, B.; Jelić, M.; Kos, T.; Benítez, H.A.; Šerić Jelaska, L. Fluctuating Asymmetry as a Method of Assessing Environmental Stress in Two Predatory Carabid Species within Mediterranean Agroecosystems. Symmetry 2020, 12, 1890. [CrossRef]

29. Palmer, A.R.; Strobeck, C. Fluctuating asymmetry analyses revisited. In Developmental Instability (DI): Causes and Consequences; Oxford University Press: Oxford, UK, 2003; pp. 279-319.

30. Brouwer, A.; Murk, A.; Koeman, J. Biochemical and physiological approaches in ecotoxicology. Funct. Ecol. 1990, 4, $275-281$. [CrossRef]

31. Eeva, T.; Tanhuanpaa, S.; Rabergh, C.; Airaksinen, S.; Nikinmaa, M.; Lehikoinen, E. Biomarkers and fluctuating asymmetry as indicators of pollution-induced stress in two hole-nesting passerines. Funct. Ecol. 2000, 14, 235-243. [CrossRef]

32. Palmer, A.R.; Strobeck, C. Fluctuating Asymmetry-Measurement, Analysis, Patterns. Annu. Rev. Ecol. Syst. 1986, 17, 391-421. [CrossRef]

33. De Coster, G.; Van Dongen, S.; Malaki, P.; Muchane, M.; Alcántara-Exposito, A.; Matheve, H.; Lens, L. Fluctuating Asymmetry and Environmental Stress: Understanding the Role of Trait History. PLoS ONE 2013, 8, e57966. [CrossRef]

34. Benítez, H.A.; Lemic, D.; Bazok, R.; Gallardo-Araya, C.M.; Mikac, K.M. Evolutionary directional asymmetry and shape variation in Diabrotica virgifera virgifera (Coleoptera: Chrysomelidae): An example using hind wings. Biol. J. Linn. Soc. 2014, 111, 110-118. [CrossRef]

35. Graham, J.H.; Emlen, J.M.; Freeman, D.C.; Leamy, L.J.; Kieser, J.A. Directional asymmetry and the measurement of developmental instability. Biol. J. Linn. Soc. 1998, 64, 1-16. [CrossRef]

36. Klingenberg, C.P.; Barluenga, M.; Meyer, A. Shape analysis of symmetric structures: Quantifying variation among individuals and asymmetry. Evolution 2002, 56, 1909-1920. [CrossRef]

37. Klingenberg, C. Analyzing Fluctuating Asymmetry with Geometric Morphometrics: Concepts, Methods, and Applications. Symmetry 2015, 7, 843-934. [CrossRef]

38. Benítez, H.A.; Vargas, H.A.; Püschel, T.A. Left-right asymmetry and morphological consequences of a host shift in the oligophagous Neotropical moth Macaria mirthae (Lepidoptera: Geometridae). J. Insect Conserv. 2015, 19, 589-598. [CrossRef]

39. Nunes, L.A.; Araújo, E.D.D.; Marchini, L.C. Fluctuating asymmetry in Apis mellifera (Hymenoptera: Apidae) as bioindicator of anthropogenic environments. Rev. Biol. Trop. 2015, 63, 673-682. [CrossRef]

40. Nattero, J.; Piccinali, R.V.; Gaspe, M.S.; Gürtler, R.E. Fluctuating asymmetry and exposure to pyrethroid insecticides in Triatoma infestans populations in northeastern Argentina. Infect. Genet. Evol. 2019, 74, 103925. [CrossRef]

41. Nattero, J.; Dujardin, J.-P.; del Pilar Fernández, M.; Gürtler, R.E. Host-feeding sources and habitats jointly affect wing developmental stability depending on sex in the major Chagas disease vector Triatoma infestans. Infect. Genet. Evol. 2015, 36, 539-546. [CrossRef]

42. Nattero, J.; Piccinali, R.V.; Lopes, C.M.; Hernández, M.L.; Abrahan, L.; Lobbia, P.A.; Rodríguez, C.S.; de la Fuente, A.L.C. Morphometric variability among the species of the Sordida subcomplex (Hemiptera: Reduviidae: Triatominae): Evidence for differentiation across the distribution range of Triatoma sordida. Parasites Vectors 2017, 10, 412. [CrossRef]

43. Di Iorio, O.; Gürtler, R.E. Seasonality and temperature-dependent flight dispersal of Triatoma infestans (Hemiptera: Reduviidae) and other vectors of Chagas disease in western Argentina. J. Med. Entomol. 2017, 54, 1285-1292. [CrossRef]

44. Navarro, G.; Maldonado, M. Geografía Ecológica de Bolivia: Vegetación y Ambientes Acuáticos; Centro de Ecología Simón I. Patiño, Departamento de Difusión: Cochabamba, Bolivia, 2002.

45. Rohlf, F.J. TPSdig; Version 2.17; State University at Stony Brook: Stony Brook, NY, USA, 2013.

46. Rohlf, F.J.; Slice, D. Extensions of the Procustes methods for the optimal superimposition of landmarks. Syst. Zool. 1990, 39, 40-59. [CrossRef]

47. Klingenberg, C.P.; McIntyre, G.S. Geometric morphometrics of developmental instability: Analyzing patterns of fluctuating asymmetry with procrustes methods. Evolution 1998, 52, 1363-1375. [CrossRef]

48. Klingenberg, C.P.; McIntyre, G.S.; Zaklan, S.D. Left-right asymmetry of fly wings and the evolution of body axes. Proc. R. Soc. B-Biol. Sci. 1998, 265, 1255-1259. [CrossRef]

49. Palmer, A.R. Fluctuating asymmetry analyses: A primer. In Developmental Instability: Its Origins and Evolutionary Implications; Springer: Berlin/Heidelberg, Geramny, 1994; pp. 335-364.

50. Klingenberg, C.P. MorphoJ: An integrated software package for geometric morphometrics. Mol. Ecol. Resour. 2011, 11, 353-357. [CrossRef]

51. Nijhout, H.; Davidowitz, G. Developmental perspectives on phenotypic variation, canalization, and fluctuating asymmetry. In Developmental Instability: Causes and Consequences; Oxford University Press: Oxford, UK, 2003; pp. 3-13. 
52. Van Dongen, S. Fluctuating asymmetry and developmental instability in evolutionary biology: Past, present and future. J. Evol. Biol. 2006, 19, 1727-1743. [CrossRef]

53. Klingenberg, C.P. Developmental instability as a research tool: Using patterns of fluctuating asymmetry to infer the developmental origins of morphological integration. In Developmental Instability: Causes and Consequences; Polak, M., Ed.; Oxford University Press: New York, NY, USA, 2003; pp. 427-442.

54. Polak, M. Developmental Instability: Causes and Consequences; Oxford University Press: Oxford, UK, 2003.

55. Benítez, H.A.; Parra, L.E. Asimetría fluctuante: Una herramienta morfo-funcional para medir estabilidad del desarrollo. Int. J. Morphol. 2011, 29, 1459-1469. [CrossRef]

56. Parsons, P. Fluctuating asymmetry: An epigenetic measure of stress. Biol. Rev. Camb. Philos. Soc. 1990, 65, 131-145. [CrossRef]

57. Benítez, H. Assessment of patterns of fluctuating asymmetry and sexual dimorphism in carabid body shape. Neotrop. Entomol. 2013, 42, 164-169. [CrossRef]

58. Benítez, H.A.; Lemic, D.; Püschel, T.A.; Gašparić, H.V.; Kos, T.; Barić, B.; Bažok, R.; Živković, I.P. Fluctuating asymmetry indicates levels of disturbance between agricultural productions: An example in Croatian population of Pterostichus melas melas (Coleptera: Carabidae). Zool. Anz. 2018, 276, 42-49. [CrossRef]

59. Woods, R.E.; Sgrò, C.M.; Hercus, M.J.; Hoffmann, A.A. The association between fluctuating asymmetry, trait variability, trait heritability, and stress: A multiply replicated experiment on combined stresses in Drosophila melanogaster. Evolution 1999, 53, 493-505. [CrossRef]

60. Vazquez-Prokopec, G.M.; Ceballos, L.A.; Kitron, U.; Gürtler, R.E. Active dispersal of natural populations of Triatoma infestans (Hemiptera: Reduviidae) in rural northwestern Argentina. J. Med. Entomol. 2004, 41, 614-621. [CrossRef] [PubMed]

61. Lazzari, C.R. Temperature preference in Triatoma infestans (Hemiptera: Reduviidae). Bull. Entomol. Res. 1991, 81, 273-276. [CrossRef]

62. Lazzari, C.; Pereira, M.; Lorenzo, M. Biología del comportamiento de los vectores de la enfermedad de Chagas. Mem. Inst. Oswaldo Cruz 2013, 108, 34-47. [CrossRef] [PubMed]

63. Roca, M.J.; Lazzari, C.R. Effects of relative humidity on the haematophagous bug Triatoma infestans: Hygropreference and eclosion success. J. Insect Physiol. 1994, 40, 901-907. [CrossRef]

64. Cecere, M.C.; Gürtler, R.E.; Canale, D.; Chuit, R.; Cohen, J.E. El papel del peridomicilio en la eliminación de Triatoma infestans de comunidades rurales argentinas. Bol. Sanit. Panam. 1996, 121, 1-10.

65. De Villar, M.; Zerba, E.; Wood, E.; De Licastro, S. Neurogenesis and occurrence of cholinesterase in eggs of Triatoma infestans. Comp. Biochem. Physiol. Part C Comp. Pharmacol. 1980, 65, 65-70. [CrossRef]

66. Leamy, L.J.; Klingenberg, C.P. The genetics and evolution of fluctuating asymmetry. Annu. Rev. Ecol. Evol. Syst. 2005, 36, 1-21. [CrossRef] 